УДК 930.1(06)

ББК 63.1

DOI 10.17150/2308-2588.2017.18(3).573-582

Н. Н. Быкова

Байкальский государственный университет, г. Иркутск, Российккая Федерация

\title{
ХІХ ИСТОРИКО-ЭКОНОМИЧЕСКИЕ ЧТЕНИЯ ПАМЯТИ В. Н. ШЕРСТОБОЕВА
}

Аннотация. Обзор выступлений участников научной конференции, посвященной памяти первого доктора экономических наук, профессора Иркутского финансово-экономического института В. Н. Шерстобоева (1900-1963).

Ключевые слова. Научная конференция, Шерстобоевские чтения, Сибирь.

N. N. Bykova

Baikal State University, Irkutsk, Russian Federation

\section{C * SCIENTIFIC CONFERENGE IN ECONOMIC HISTORY IN MEMORY OF $\boldsymbol{V}$. N. SHERSTOBOEV}

Abstract. This paper analyzes reports of the participants of the scientific conference dedicated to the memory of V. N. Sherstoboev (1900-1963) - the first Doctor of Economics, Professor of the Irkutsk Finance and Economics Institute.

Keywords. Scientific conference, Sherstoboev conference, Siberia.

В течение последних девятнадцати лет в Байкальском государственном университете (БГУ) проводится научная конференция, посвященная памяти первого доктора экономических наук, профессора Иркутского финансово-экономического института В. Н. Шерстобоева. Данная конференция - Шерстобоевские чтения, - объединяет исследователей истории Сибири. 
Разнообразие исторических тем, рассматриваемых не только историками, но и экономистами, социологами, географами, философами и даже математиками, представляет болышой интерес, как для коллег-учёных, так и для широкой аудитории слушателей, которые интересуются прошлым и настоящим сибирского региона.

В девятнадцатых чтениях, прошедших в Байкальском государственном университете 23-24 марта 2017 г. приняли участие 70 авторов, из них 20 докторов и 36 кандидатов наук, преподавателей, аспирантов, соискателей, научных сотрудников из разных вузов, что свидетельствует о широкой известности и популярности данной конференции. По сложившейся традиции к началу конференции был издан очередной том «Иркутского историко-экономического ежегодника»

С приветственным словом к участникам конференции обратилась проректор по научной работе Байкальского государственного университета Т. Л. Музычук, напомнившая слушателям о большой подготовительной работе, проделанной коллективом кафедры истории и международных отношений, являющейся организатором этого замечательного мероприятия, а также о значимости проводимой научной конференции. Пожелала всем присутствующим плодотворной работы и научных успехов.

С большим интересом участники конференции заслушали доклад доктора исторических наук, профессора БГУ А. В. Шалака на тему «Некоторые историко-геополитические штрихи к портрету А. В. Колчака». Имя Колчака достаточно известно, в его биографии с Иркутском связано немало событий. Обосновывая актуальность предлагаемой темы, Александр Васильевич акцентировал внимание на противоречивых мнениях по поводу анализируемой личности и пришел к выводу

* Иркутский историко-экономический ежегодник: 2017. Иркутск: Изд-во БГУ, 2017. - 552 с. 
о необходимости развеять навязываемые мифы о деятельности Колчака. Автор считает, что только на основе геополитического подхода можно наиболее объективно оценить роль личности Колчака. И действительно, в чьих интересах он действовал? В интересах сбережения России, ее безопасности или играл на стороне ее геополитических противников, стремящихся установить контроль над ресурсами России?

Докладчик уточнил, что основные ресурсы планеты сосредоточены на евразийском континенте, и кто будет их контролировать, зависит от соотношения сил. В начале XX в. это мог быть союз динамично развивающихся государств - Германии и России, или морских держав, прежде всего, - Великобритании. Столкновение в военном конфликте Германии и России привело бы к истощению и ослаблению этих стран, что в результате позволило бы англосаксонскому миру установить контроль над Евразией. И англосаксы сумели переиграть всех. Последствия известны - две мировые войны, распад советской государственности, антироссийские санкции и др.

Затем А. В. Шалак на основе исследовательских работ ряда авторов остановился на анализе позиции Колчака в геополитическом раскладе и пришел к выводу, что было тесное сотрудничество с заграницей (плен у японцев, после плена побывал в США и Англии, открытое поступление на службу к последней в 1917 г.), приглашение иностранных вооруженных формирований, бунт и восстание при поддержке иностранных государств, расхищение и передача иностранным правительствам достояний советской республики. Это и есть измена Родине, переход на сторону врага, шпионаж, диверсия и т. д. Таково истинное лицо данного человека. И, как следствие, Колчак был расстрелян в Иркутске.

В своем выступлении «"Большая и грустная ошибка": газета “Деловая Сибирь” и полемика по “университетскому" вопросу, 1916-1917 гг.» многолетний 2017. T. 18, № 3. C. 573-582 
участник конференции кандидат экономических наук, доцент Д. Я. Майдачевский рассмотрел особую позицию редакции иркутской газеты «Деловая Сибирь» в развернувшейся на страницах местных средств массовой информации в период образовательных реформ П. Н. Игнатьева (1915-1916 гг.) полемике по «университетскому» вопросу. Последний был поставлен в принципиально новой плоскости: как о наиболее желательном для Сибири типе высшего учебного заведения, а не месте его расположения. Со всей определенностью редакционные публикации продвигали идею приоритетности для региона новой формы народнохозяйственного института - политехникума.

Газета, по словам докладчика, не упускала ни малейшей возможности проинформировать читателей об отрадных на ее взгляд событиях сибирской жизни, свидетельствовавших об изменении в настроениях общественности в вопросе народнохозяйственного образования, небезосновательно полагая, что «эти факты красноречивее сомнительных теоретических рассуждений со ссылками на исторические предпосылки». Однако самые обнадеживающие известия приходили из столицы, где, как информировала на своих страницах газета, «в тиши канцелярского лабиринта министерства народного просвещения чиновники сидели и разрабатывали вопрос о сети новых институтов в Империи, - главным образом в Сибири. И мы этим чиновникам обязаны за теоретическое обоснование политехникума...». В тиши министерских кабинетов рождалась новая концепция политехнической организации инженерно-хозяйственного образования, которая ляжет в основание долгосрочной программы развития народнохозяйственной школы в стране. В соответствии с нею в Иркутске должен был появиться отнюдь не университет, а политехникум. История, как известно, распорядилась иначе. Не только оппозиция упомянутому проекту в Комиссии по реформе высшей 
школы Временного правительства, но и «демократическая контрреволюция» в Сибири, привели к открытию в Иркутске «классического» университета, против чего и небезосновательно выступала немалая часть общественности города.

Гость из г. Улан-Удэ, доктор исторических наук, профессор института железнодорожного транспорта, Ч. Г. Андреев выступил с докладом на тему «Новации в жизни коренных народов Восточной Сибири во второй половине XIX - начале XX века», в котором проанализировал изменения в материальной и духовной жизни аборигенов Восточной Сибири указанного периода. На основе архивных источников была приведена статистика численности коренного населения Восточной Сибири, которая имела тенденцию увеличения в период со второй половины XIX в. и до начала XX века. Далее докладчик остановился на причинах роста численности сибирских народов, в частности бурят, хакасов, якутов. Большое влияние оказывало русское население и как следствие - распространение земледелия, со временем получившего товарную направленность. Что касается скотоводства, то и оно претерпело изменения в связи с развитием капиталистических отношений. Кроме того, в этот период распространяются «отхожие» промыслы, в частности, извоз, сплав леса, работа на приисках и прокладка дорог и др.

Экономическая составляющая повлияла на культуру коренных народов, в том числе происходили изменения в одежде, стремление к получению образования, участие в периодической печати (стали издавать свои газеты, журнал). Кроме того, Чингис Георгиевич остановился на христианизации нерусских народов, которая имела большое значение. В связи с переходом к православию аборигены расширяли и активизировали хозяйственно-экономические и культурные связи с русским населением, овладевали русским языком, усиливалась их мобильность и социальная активность. 
В продолжение темы выступил кандидат исторических наук, доцент кафедры истории и международных отношений БГУ А. М. Курышов с докладом «Экономические предпосылки реформирования землепользования бурят Иркутской губернии в конце XIX - начале XX в.». Говоря о широкомасштабной реформе землепользования крестьян Сибири, Андрей Михайлович акцентировал внимание на позиции социал-демократов начала XX века в оценке этой реформы, которая, по их мнению, заключалась в антинародных действиях правительства. Эта позиция достаточно популярна среди историков и сегодня. Поэтому исследователь в своем докладе предложил разобраться, а были ли объективные хозяйственные предпосылки реформирования системы землепользования коренного населения Сибири.

На основе многочисленных источников выступающий пояснил, что основным содержанием земельной реформы было ограничение земель до 15 десятин на душу, находящихся в пользовании. Но «инородцы» имели некоторые привилегии, в частности, кроме пашенной земли, они получали до 3 десятин на душу леса, по 15 десятин на душу выгонных степей (для скота), имели возможность выбора удобных земель. Однако установленные нормы вызвали сопротивление бурятского населения, и землеустроительные работы были временно приостановлены. В 1906 г. землеустроительные работы вновь продолжились. Необходимы ли были они? Ведь были сторонники и противники реформы.

Тот факт, что на рубеже веков у бурят Иркутской губернии было развито земледелие, не вызывает сомнения. Однако, в ряде уездов у инородцев площади усадьбы и пашни были значительно меньше, чем площади покосов. Причем часть покосных земель состоятельное бурятское население сдавало в аренду. Но в целом размеры пашни у бурят были велики. Очень умело Андрей Михайлович дал многие показатели в презентации и объективно, на наш взгляд, их ком- 
ментировал. В заключении ученый сделал вывод, что реформа землеустройства была не только возможной, но и желательной. Ведь земля была необходима всем, но размеры наделов были разными. А реформа позволила перераспределить излишки в пользу беднейших слоев бурятского населения (нормы для всех одни), а кроме того, излишки земли могли быть использованы для нужд переселенцев.

Об особенностях организации оптовой пушной торговли рассказала в докладе «Переписка представителей акционерного общества спичечной и меховой фабрики “Н. П. Рылов и Ф. П. Лесников” как источник по изучению проблем развития оптовой пушной торговли в Северо-Восточной Сибири в начале XX в.» доктор исторических наук, доцент кафедры сервиса и сервисных технологий Иркутского государственного университета М. Д. Кушнарева. Акционерное общество спичечной и меховой фабрики «Н. П. Рылов и Ф. П. Лесников» имело миллионные годовые обороты в сфере пушной торговли, лидирующие позиции во внешней пушной торговле как сырыми, так и выделанными мехами, которые производились на меховой фабрике в с. Слободском Вяткинской губернии с головной конторой в Москве. По словам историка в исследуемый период предприятия с крупным капиталом занимались развитием пушной торговли и снабжением товарами промыслового населения Крайнего Севера, а эпистолярное наследие, сохранившееся до наших дней, позволяет детально изучить особенности организации оптовой торговли на севере Якутской области. Ссылаясь на письма бухгалтера Акционерного общества Ивана Яковлевича Перевалова, докладчик сообщила, что все сделки носили меновый характер. Тунгус или якут, бравший у торговца в долг товар первой необходимости, считал обязанным отдать весь свой промысел своему кредитору. Приезжие купцы уделяли большое внимание соблюдению традиций местных жителей. К примеру, чтобы не оби2017. T. 18, № 3. C. 573-582 
деть аборигенов-промышленников и закрепить с ними прочные деловые связи, приезжие торговцы должны были переночевать у них, угостить их, поиграть в карты. Докладчик процитировала строчку из письма Перевалова «личные отношения в торговле северной имеют огромное значение».

Исследователь акцентировала внимание на высоком уровне конкуренции среди фирм. Фирмы, имеющие собственный речной транспорт, склады в портах Охотского моря и возможности проводить оптовую торговлю товарами первого потребления были более привлекательными для промысловиков и скупщиков именно этим фирмам, в основном, и сбывали сырье. Акционерное общество спичечной и меховой фабрики «Н. П. Рылов и Ф. П. Лесников» скупала пушнину за наличные деньги, тем самым теряя клиентов, поскольку им купить товары в условиях северной торговли было почти невозможно. Чтобы удержать позиции на рынке акционеры стали скупать пушнину за наличные деньги на ярмарках Северо-Восточной Сибири, даже по завышенной цене. В 1919 г. Акционерное общество спичечной и меховой фабрики «Н. П. Рылов и Ф. П. Лесников» прекратило свое существование, а все имущество Якутского отделения было национализировано.

Подводя итоги своего выступления, М. Д. Кушнарева выразила уверенность в том, что степень достоверности данных изученной ею переписки сибирских торговцев достаточно высока и позволяет не только передать особенности ведения дел исследуемого периода, но и передать образ мыслей и даже настроение успешных предпринимателей прошлого.

Аспирант кафедры истории и международных отношений Байкальского государственного университета Д. В. Скрипучий выступил с докладом «Состояние безопасности на узкоколейных железных дорогах Байкальского региона». Он рассказал, что на первоначальном этапе массовой эксплуатации узкоколеек в XX веке 
именно тема аварийности стояла в числе самых острых проблем. Исследователь остановился на типовых примерах угроз жизни и имуществу со стороны этого вида транспорта. Кроме того, акцентировал внимание на некоторых мерах по улучшению условий эксплуатации, которые, к сожалению, носили эпизодический характер, поэтому несчастные случаи повторялись. Докладчик упомянул, что статистика по аварийности в узкоколейной отрасли, представлена в малом количестве источников и далеко не в полном объеме - мелкие аварии, как правило, скрывались от руководства.

Наиболее часто несчастные случаи, в том числе с летальным исходом, на узкоколейных железных дорогах в исследуемый период происходили из-за некачественно проведенных инженерно-геологических изысканий, поспешного необоснованного допуска дорог к эксплуатации, их запущенного состояния, неудовлетворительного технического состояния инфраструктуры, отсутствия графиков движения поездов, неисправности подвижного состава, низкого уровня компетентности локомотивных бригад, несоблюдения элементарной техники безопасности, в том числе по причине алкогольного опьянения участников дорожного движения. Летальные исходы по причине наездов поездов на пешеходов тоже фиксировали довольно часто. Дмитрий Владимирович сделал вывод, что во многом неосмотрительные и легкомысленные действия граждан объясняются несерьезным отношением к узкоколейным дорогам, в том числе по причине их низких скоростей. Завершая свое выступление Дмитрий Владимирович констатировал тот факт, что несмотря на трагические инциденты и прямые экономические потери, борьба с аварийностью на узкоколейных железных дорогах не являлась приоритетной для управляющих организаций и никогда не проводилась системно.

В данном обзоре были рассмотрены лишь некоторые выступления участников XIX ежегодной научной 2017. T. 18, № 3. C. 573-582 
конференции, посвященной памяти Вадима Николаевича Шерстобоева. Тематика представленных работ оказалась разнообразной, выступления ученых были выслушаны с большим интересом, в обсуждении докладов приняли участие многие участники конференции. С содержанием всех докладов, представленных на конференцию, можно познакомиться, обратившись к Иркутскому историко-экономическому ежегоднику, текст которого размещен на странице Регионального центра научных исследований экономической истории России на сайте БГУ - http:/ / history.isea.ru/hee/

\section{Информация об авторе}

Бъкова Нина Николаевна - кандидат исторических наук, доцент, кафедра истории и международных отношений, Байкальский государственный университет, Российская Федерация, 664003, г. Иркутск, ул. Ленина, 11, e-mail: bykovann@yandex.ru

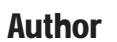

Bykova Nina Nikolaevna - PhD in History, Associate Professor, Department of History and International Relations, Baikal State University, 11, Lenin Str., Irkutsk, 664003, Russian Federation, e-mail: bykovann@yandex.ru

\section{Для цитирования}

Быкова Н. Н. XIX Историко-экономические чтения памяти В.Н. Шерстобоева / Н. Н. Быкова / / Историкоэкономические исследования. - 2017. - Т. 18, № 3. C. 573-582. - DOI: 10.17150/2308-2588.2017.18(3).573-582.

\section{$47: 4$ 제}

Bykova N. N. 19th Scientific Conference in Economic History in Memory of $\mathrm{V}$. N. Sherstodoev. Istorikoekonomicheskie issledovaniya = Journal of Economic History $\mathcal{E}$ History of Economics, 2017, vol. 18, no. 3, pp. 573-582. DOI: 10.17150/2308-2588.2017.18(3).573-582. (In Russian).. 